\title{
GESTÃO DAS ÁGUAS MINERAIS NO BRASIL - PANORAMA LEGAL ATUAL E PERSPECTIVAS FUTURAS
}

\author{
Ana Lúcia Desenzi GESICKI \\ Francesco SINDICO
}

\begin{abstract}
RESUMO
As águas minerais no Brasil são tratadas juridicamente como recursos minerais, possuem legislação própria (Código de Águas Minerais de 1945) e seguem os fundamentos e instrumentos de outorga de direitos da legislação que regulamenta a atividade de mineração no país. Estes princípios conflitam com a própria Constituição Federal de 1988, que delegou o domínio das águas subterrâneas aos Estados. Além disso, a legislação ambiental e de recursos hídricos, promulgadas a partir da década de 1980, introduziram uma dimensão ambiental às águas como um todo, incluindo os recursos hídricos subterrâneos, definindo-as como bens de domínio público e de uso comum do povo, de caráter não dominial e inalienável. As águas minerais foram legalmente definidas na década de 1940 como águas subterrâneas naturalmente potáveis, protegidas da contaminação superficial, de composição química regularmente definida e presumível ação medicamentosa. Alguns conceitos originais da legislação de águas minerais foram profundamente modificados com o tempo, principalmente no que se refere ao estudo da ação terapêutica destas águas e seu uso em balneários e estâncias hidrotermais. Atualmente o aproveitamento econômico das águas minerais é primordialmente voltado à produção de bebidas engarrafadas e as características químicas e físico-químicas da maior parte de suas fontes revelam que hoje as águas minerais pouco se diferenciam das águas subterrâneas de composição ordinária. No momento político atual, em que se discute a mudança do marco legal da mineração no país, é desejável retomar a discussão, em nível governamental, para atualizar a lei das águas minerais, levando em consideração os conhecimentos modernos de hidrogeologia, química e medicina, assim como os fundamentos de proteção do meio ambiente e de desenvolvimento sustentável introduzidos pela Constituição. Defende-se aqui um debate franco, aberto e democrático, que conte com a participação dos diversos setores da sociedade com interesses conflitantes no uso de recursos hídricos subterrâneos.
\end{abstract}

Palavras-chave: águas minerais, recursos hídricos subterrâneos, Constituição, legislação mineral.

\section{ABSTRACT}

MINERAL WATER MANAGEMENT IN BRAZIL - CURRENT LEGAL OVERVIEW AND FUTURE PERSPECTIVES. Mineral waters in Brazil are legally treated as a mineral resource, have their own specific legislation (1945 Code of Mineral Waters), which follows the general procedures for granting rights regarding mining activity in Brazil. These principles are in conflict with both the 1988 Federal Constitution, which delegates the domain over groundwater to the States, as well as the legislation regarding the environment and water resource management that came into force in the 1980s. Modern legislation has introduced an environmental dimension to waters in general, including groundwater, and defined it as an inalienable public good for common use. Mineral waters are defined by law as potable groundwaters of regular chemical composition and presumed medicinal action, protected from surface contamination. Some original concepts of the mineral water law have been profoundly changed especially with regard to their therapeutic effect and use in spas and hydrothermal resorts. Nowadays, mineral 
waters are primarily used in the production of bottled beverages, and they are barely distinguishable from ordinary groundwater in terms of chemical and physical-chemical composition. The current political climate in Brazil is particularly favorable for reopening the discussion for updating mineral water legislation because the National Congress is evaluating a bill regarding new legislation for the Brazilian mining sector. The law-making process for mineral waters should take into account modern concepts of hydrogeology, chemistry and medicine, as well as the fundamentals of sustainable development and protection of the environment introduced by the Constitution. It is highly recommended that this issue be subject to an open-minded, transparent and democratic debate, with full participation of government institutions and the various sectors of society that have competing interests in the use of groundwater resources.

Keywords: mineral waters, groundwater resources, Constitution, mineral legislation.

\section{INTRODUÇÃO}

A indústria das águas engarrafadas é o segmento industrial do ramo das bebidas não alcoólicas que mais cresce no mundo, superando o consumo de chá, leite e refrigerantes. Segundo dados da Zenith International (WILTON 2011), foram consumidos mundialmente 239 bilhões de litros de água engarrafada em 2011, o que representa um aumento de $6,3 \%$ em relação ao consumo do ano anterior (225 bilhões de litros). No Brasil, o consumo estimado de água mineral engarrafada foi de 13,7 bilhões de litros em 2010 (ABIR 2011), ocupando a segunda posição em relação às bebidas não alcóolicas mais consumidas, atrás apenas dos refrigerantes.

As águas minerais brasileiras são na verdade uma commodity, tratadas juridicamente como recursos minerais e cuja produção é voltada ao mercado de bebidas industrializadas, seja ele nacional ou importado. A principal diferença entre as águas minerais engarrafadas e outras commodities minerais reside no fato de que as primeiras não podem ser tratadas ou terem sua composição original modificada; as outras commmodities passam necessariamente pelo processo de beneficiamento, o qual traz profundas alterações do recurso mineral extraído, não só físicas, mas também do ponto de vista químico e mineralógico. A segunda principal diferença é que a água mineral é produzida diretamente para consumo humano.

No Brasil, águas minerais e recursos hídricos subterrâneos são bens públicos distintos, que estão sob domínio de diferentes esferas da administração pública, respectivamente, a federal e a estadual. Além disto, são recursos geridos isoladamente e de forma não integrada. O motivo principal para esta falta de integração reside no fato de que a legislação brasileira de águas minerais é bastante antiga (Código de Águas Minerais de 1945), anterior à Constituição Federal de 1988, e não foi incorporada à legislação que regulamenta o uso de recursos hídricos superficiais e subterrâneos, mais moderna, promulgada na década de 1990 (Lei das Águas de 1997).

Em países como os Estados Unidos e o Reino Unido, há uma discussão polêmica entre a indústria de bebidas envasadas e entidades civis que defendem o consumo de água de torneira, provida por abastecimento público. A principal crítica está na "comoditização" e na geração desnecessária de resíduos sólidos que a indústria da água engarrafada produz, além do argumento de que a água é um recurso essencial à vida e deveria constituir um direito humano básico. Argumenta-se que em países pobres há crescimento do setor industrial de produção da água engarrafada, pois invariavelmente verifica-se falha nos sistemas de abastecimento público de água potável; em países ricos, onde a boa qualidade da água de torneira é inquestionável, consumir água envasada é reflexo do alto poder de consumo da população e do bem sucedido marketing do setor de bebidas (WILK 2006). No Brasil, a discussão ainda está em outro nível, mais primário, de considerar ou não as águas minerais também como recursos hídricos ou alimentos, além de serem recursos minerais.

Este artigo pretende abordar a discussão em torno do arcabouço jurídico das águas minerais brasileiras, o qual se mostra um assunto polêmico. A intenção deste artigo é instigar a discussão na comunidade geológica e no âmbito governamental sobre a necessidade premente de revisar os conceitos legais e fundamentos vigentes para o aprovei- 
tamento econômico das águas minerais no Brasil, com foco nas legislações ambiental e de recursos hídricos, as quais introduziram um valor ambiental irretratável às águas subterrâneas como um todo, sejam elas mineralizadas ou não. A forma como a sociedade brasileira lida atualmente com os recursos ambientais e hídricos é substancialmente distinta daquela vigente na década de 1940, quando a legislação de águas minerais foi promulgada. As águas minerais eram reconhecidas, nesta época, como produtos medicinais, ao passo que hoje em dia são bens de consumo extremamente populares e acessíveis, representantes de um segmento industrial em franca expansão no Brasil e no mundo.

Este assunto tem pouca atenção na literatura geológica e na área jurídica, apesar da indiscutível interface de gestão das águas minerais com a dos recursos hídricos subterrâneos. Este artigo aborda o tema da seguinte maneira: primeiro apresenta um panorama geral do marco legal brasileiro das águas minerais, como se caracteriza o segmento produtivo hoje e como é feita a gestão deste recurso. Em seguida, é apresentada uma reflexão a respeito da constitucionalidade da legislação afeta às águas minerais, tendo por base os fundamentos da Constituição Federal de 1988 e a legislação posterior de recursos hídricos. Por fim, o artigo defende a necessidade de ampla discussão pela sociedade brasileira visando à revisão da legislação de águas minerais no país.

\section{2 ÁGUAS MINERAIS - ARCABOUÇO LEGAL}

A gestão das águas minerais no Brasil está inserida no contexto da gestão dos recursos minerais, de competência do Departamento Nacional de Produção Mineral (DNPM), autarquia federal vinculada ao Ministério de Minas e Energia (MME). A base legal desta gestão reside em Decretos-Lei promulgados durante governos autoritários, o Decreto-Lei n ${ }^{\circ} 7.841$ de 08/08/1945 - Código de Águas Minerais (CAM) e o Decreto-Lei no 227 de 27/02/1967 - Código de Mineração (CM), ambos em vigor. Os regimes legais que regem a outorga de direitos para o aproveitamento econômico das águas minerais são os de Autorização e Concessão, definidos no Art. $2^{\circ}$, I e II do CM, combinado ao Art. $4^{\circ}$ do CAM.

Considerando os dispositivos legais do CAM e do CM, a água mineral é um recurso mineral dotado de valor econômico. A Constituição Federal de 1988 (CF), por sua vez, atribui a propriedade dos recursos minerais à União e a considera dis- tinta da propriedade do solo (Art. 176, CF). A exploração ou aproveitamento dos recursos minerais depende de autorização ou concessão federal (Art. $176, \mathrm{CF}$ ), sendo de competência privativa da União legislar sobre esta matéria (Art. 22, XII, CF).

O CAM define as águas minerais como aquelas "provenientes de fontes naturais ou de fontes artificialmente captadas que possuam composição química ou propriedades físicas ou físico-químicas distintas das águas comuns, com características que lhes confiram uma ação medicamentosa" (Art. $1^{\circ}, \mathrm{CAM}$, grifos nossos). Os parâmetros químicos e físico-químicos das águas subterrâneas mineralizadas e respectivas fontes, responsáveis por alguma ação medicamentosa, foram definidos nos Art. 35 e 36 do CAM e constituem características quanto à composição química, ao teor de gases dissolvidos e à temperatura da água na fonte.

Legalmente, a ação medicamentosa de uma água subterrânea que possui composição química constante ou propriedades físico-químicas peculiares é condição necessária para ser classificada como mineral. Por outro lado, o CAM define, nos Art. 35 e 36, os parâmetros químicos e físicos que presumivelmente estão associados a algum efeito medicamentoso. Desta forma, não há requisito legal para atestar o uso terapêutico de uma água subterrânea (exceto para água classificada como oligomineral, nitratada e cloretada). Ao atingir os parâmetros legais de determinados compostos químicos, independente de testes empíricos ou comprovação clínica de possíveis efeitos medicamentosos, a água subterrânea pode ser classificada como mineral.

O CAM estabeleceu a Comissão Permanente de Crenologia (Art. $2^{\circ}, \mathrm{CAM}$ ) como a instância técnica adequada para reconhecer, aprovar ou fiscalizar a ação medicamentosa de uma água classificada como mineral. Desde sua origem, em 1948, até 1959, quando foi extinta, a Comissão Permanente de Crenologia (CPC) cumpriu efetivamente o papel de fiscalizar as propriedades terapêuticas das águas minerais, pois contava com a colaboração de médicos crenologistas reconhecidos, como por exemplo, o Dr. Fabrino Lopes (CAETANO 2005).

A CPC em sua forma e composição originais foi extinta por mais de 30 anos, de 1959 a 1993, e de 1999 a 2005 (CAETANO 2005). Em 2005, o Diretor Geral do DNPM retomou os trabalhos da referida Comissão e definiu um novo Regimento Interno (Portaria MME no 52/2005), com o objetivo de recuperar um importante instrumento de gestão e de valorização das águas minerais no Brasil, tendo por base o fiel cumprimento do Código 
de Águas Minerais. A CPC subsiste em sua nova forma e tem atualmente um papel importante como fórum de discussão normativa, por agregar profissionais do DNPM, da área da saúde e do setor produtivo. No entanto, o papel original da CPC, de fiscalizar as propriedades medicamentosas das águas minerais, não é mais efetivo como foi no passado, visto que a colaboração de médicos crenologistas é pontual e eventual, devido à extinção desta especialidade médica no Brasil (QUINTELA 2004 a, b). Com a extinção da especialidade médica Crenologia (também conhecida por Hidrologia Médica), reconhecida pelo respectivo conselho de classe no Brasil, perdeu-se o foco sobre a ação medicamentosa da água mineral desde pelo menos a década de 1960 (CAETANO 2005).

O CAM foi promulgado em 1945, num momento de consolidação de estabelecimentos hidrotermais como importantes centros de tratamento de males à saúde, no auge da fase de popularização de práticas médicas com uso de águas minerais e termais (QUINTELA 2003, 2004 a, b). No entanto, as estâncias hidrotermais ou hidrominerais, que antes eram considerados verdadeiros centros de cura, entraram em declínio e foram readequadas nos últimos trinta anos como centros de turismo de lazer ou, eventualmente, turismo de saúde (QUINTELA $2004 \mathrm{a}, \mathrm{b}$ ). Muitos dos tradicionais balneários hidrotermais estão hoje em dia em condições precárias de conservação (ABINAM 2012) e seus gestores muitas vezes não atendem às exigências da legislação vigente nem dos órgãos fiscalizadores, por exemplo, no que se refere ao monitoramento da qualidade da água mineral, manutenção de fontes e fontanários, entrega de relatório anual de lavra, entre outros.

Atualmente não é possível ao DNPM ou à CPC cumprir estritamente o Código de Águas Minerais, uma vez que praticamente não há mais médicos especialistas que possam atestar a ação medicamentosa de uma água. O que o DNPM faz, de fato, é classificar uma água como mineral em função exclusivamente da sua composição química ou das propriedades físico-químicas da água na fonte. O parâmetro determinante para a classificação de uma água mineral é a potabilidade natural (química e bacteriológica) e, secundariamente, a composição química regularmente definida e certas propriedades físico-químicas da água na fonte, conforme definidas em lei. A potabilidade química e bacteriológica das águas minerais deve atender aos parâmetros definidos nas Resoluções n ${ }^{\circ}$ 274/2005 e $n^{\circ}$ 275/2005 da ANVISA, respectivamente.

\section{3 ÁGUAS MINERAIS - PROPRIEDADES NATURAIS E PROCEDIMENTOS DE CLASSIFICAÇÃO}

No âmbito do CAM, o termo "águas minerais" é utilizado no sentido amplo, para designar um grupo de águas subterrâneas mineralizadas com características especiais, diferenciadas das "águas comuns", com composição química regularmente definida e presumível ação terapêutica. Em sentido estrito, águas minerais englobam as seguintes categorias: oligomineral, radífera, alcalino-bicarbonatada, alcalino-terrosa, alcalino-terrosa cálcica, alcalino-terrosa magnesiana, sulfatada, sulfurosa, nitratada, cloretada, ferruginosa, radioativa, toriativa e carbogasosa (Art. 35, CAM). O Art. 35 do CAM estabelece os limites mínimos dos teores dos respectivos compostos químicos e define que uma água pode ter classificação mista se apresentar em sua composição mais de um elemento ou composto, assim como elementos químicos "dignos de nota" (iodo, arsênio, lítio, etc.). O Art. 36, por sua vez, especifica propriedades da água na fonte que são intermitentes, como teor de gases radioativos temporários (radônio e torônio) e de gás sulfídrico, além da temperatura. Estas características são acessórias à composição química, conforme definido no Art. 35, e servem para descrever e classificar uma fonte de água mineral.

Além das águas minerais, o CAM reconhece o grupo das "águas comuns", que seriam as águas subterrâneas de composição normal, ordinária, de geoquímica não diferenciada num aquífero. As "águas comuns" são aquelas fracamente mineralizadas, ou não termais, ou não naturalmente gasosas, ou não radioativas, ou não destinadas a fins balneários, as quais teoricamente não estão associadas a nenhum efeito medicamentoso imediato. As "águas comuns" podem ser utilizadas para envase desde que atinjam os padrões legais de potabilidade. Se adequadas ao envase, tais águas são denominadas no CAM como "água potável de mesa" e são consideradas recursos minerais de propriedade da União, geridas pela legislação afeta ao setor de mineração, da mesma forma que as águas minerais.

Utiliza-se neste trabalho o termo "águas minerais" no sentido amplo (l.s.), para todas aquelas águas de suposta ação medicamentosa, reguladas pelo CAM. O termo "águas comuns" e "águas subterrâneas de composição normal" são aqui referidas, respectivamente, como aquelas não medicamentosas e não reguladas pelo CAM.

Pela interpretação estrita do CAM, águas minerais possuem algum efeito medicamentoso 
imediato, efeito este que presumivelmente está associado à presença de compostos químicos específicos, ao teor de determinados gases dissolvidos e à radioatividade natural. A lei define os diversos tipos de água mineralizada conforme as concentrações de compostos químicos definidos no Art. 35, incisos I a XII, observando-se as situações de exceção previstas no seu $\S 2^{\circ}$ (combinado ao Art. $1^{\circ}, \S 3^{\circ}$ ) para as águas oligominerais, nitratadas e cloretadas. Ressalta-se que o legislador considerou a eventualidade de algum efeito medicamentoso da água de baixo grau de mineralização (oligomineral) e daquela com nitrato e cloreto (componentes químicos tipicamente antrópicos e comumente associados à contribuição de águas contaminadas), mas sabiamente determinou a necessidade de realização de testes empíricos prévios, realizados por médicos crenologistas, desde que posteriormente aprovados pela própria CPC, para atestar o seu uso medicamentoso.

Considerando as características da composição química relacionadas no Art. 35 do CAM, as águas minerais deveriam ter baixo a médio grau de mineralização, com concentração de compostos dissolvidos de no mínimo $100 \mathrm{mg} / \mathrm{L}$ (Tabela
1). Observar que a água ferruginosa e a água cloretada necessariamente são de alta mineralização, visto que as concentrações isoladas do cátion ferro e do cloreto de sódio, respectivamente, devem ser maiores que $500 \mathrm{mg} / \mathrm{L}$. O grau de mineralização é indiferente apenas em águas com emanação natural de gás sulfídrico e na presença de elementos radioativos, sejam eles permanentes (a água radífera, que contém Rádio) ou temporários (a água radioativa, que contém Radônio, e a água toriativa, que contém Torônio). Neste sentido, é compreensível que o CAM defina as águas oligominerais dentro dos casos de exceção previstos no Art. $1^{\circ}$, $\S 3^{\circ}$, como águas que necessitam de testes clínicos e aprovação da CPC quanto aos possíveis efeitos medicamentosos, por serem águas de baixa mineralização, eventualmente portadoras de elementostraços notáveis.

Com o passar dos anos, o corpo técnico do DNPM, com respaldo da própria CPC, alterou progressivamente a forma de interpretar o CAM visando à classificação de uma água subterrânea como mineral (CAETANO 2005, SERRA 2009). Com a mudança de interpretação da lei, o DNPM

TABELA 1 - Parâmetros de composição química das águas minerais conforme Art. 35 do CAM.

\begin{tabular}{|c|c|c|}
\hline Tipo de água mineral & $\begin{array}{c}\text { Concentração mínima de compostos } \\
\text { químicos }\end{array}$ & Observações \\
\hline Oligomineral & Não definida & $\begin{array}{l}\text { Necessita de testes clínicos prévios e } \\
\text { aprovação da CPC }\end{array}$ \\
\hline Radífera & Não definida, presença de Ra & Radioatividade permanente \\
\hline Alcalino-bicarbonatada & $>200 \mathrm{mg} / \mathrm{L}$ de $\mathrm{NaHCO}_{3}$ & \\
\hline Alcalino-terrosa & $>120 \mathrm{mg} / \mathrm{L} \mathrm{de} \mathrm{CaCO}_{3}$ & \\
\hline Sulfatada & $\begin{array}{c}>100 \mathrm{mg} / \mathrm{L} \text { de } \mathrm{SO}_{4}^{-2} \text { combinado aos } \\
\text { cátions } \mathrm{Na}^{+}, \mathrm{I}^{+2}, \mathrm{Mg}^{+2}\end{array}$ & \\
\hline Sulfurosa & $>1 \mathrm{mg} / \mathrm{L}$ do ânion $\mathrm{S}^{-2}$ & Com emergência do gás sulfídrico \\
\hline Nitratada & $>100 \mathrm{mg} / \mathrm{L}$ de $\mathrm{NO}_{3}^{-}$de origem mineral & $\begin{array}{l}\text { Necessita de testes clínicos prévios e } \\
\text { aprovação da CPC }\end{array}$ \\
\hline Cloretada & $>500 \mathrm{mg} / \mathrm{L} \mathrm{de} \mathrm{NaCl}$ & $\begin{array}{l}\text { Necessita de testes clínicos prévios e } \\
\text { aprovação da CPC }\end{array}$ \\
\hline Ferruginosa & $>500 \mathrm{mg} / \mathrm{L} \mathrm{de} \mathrm{Fe}^{+2+3}$ & \\
\hline Radioativa & $\begin{array}{c}>5 \mathrm{Mache} / \mathrm{L} \text { de } \mathrm{Rn} \text { a } 20{ }^{\circ} \mathrm{C} \text { e } 760 \\
\mathrm{mmHg} \text { (pressão) }\end{array}$ & Radioatividade temporária \\
\hline Toriativa & Não definida, >2 Mache/L de Tn & Radioatividade temporária \\
\hline Carbogasosa & $\begin{array}{c}>200 \mathrm{mg} / \mathrm{L} \mathrm{de} \mathrm{CO}_{2} \text { livre a } 20^{\circ} \mathrm{C} \mathrm{e} 760 \\
\mathrm{mmHg} \text { (pressão) }\end{array}$ & Com emergência do gás carbônico \\
\hline
\end{tabular}


passou a classificar como minerais águas de baixa e baixíssima mineralização, sem que estas atingissem as concentrações dos compostos definidos no Art. 35 do CAM. Passou-se a adotar o critério de classificação de uma água mineral com base exclusivamente na presença de elementos dignos de nota (por exemplo, "água mineral fluoretada", devido à presença de fluoreto em qualquer concentração) ou exclusivamente devido à temperatura da água na fonte (por exemplo, "água mineral hipotermal" para uma água de baixa mineralização, sem nenhum oligoelemento notável e cuja temperatura na fonte situa-se entre 25 e $30^{\circ} \mathrm{C}$ ). Segundo este procedimento, praticamente qualquer água subterrânea naturalmente potável pode hoje ser classificada como água mineral pelo DNPM.

O procedimento de classificar uma água mineral exclusivamente pela temperatura ou quantidades insignificantes de fluoreto, ou qualquer outro elemento-traço, parece-nos equivocado e em desacordo com os fundamentos legais do CAM por um motivo muito simples: tais parâmetros não permitem diferenciar de forma inequívoca águas minerais das "águas comuns", ou seja, não são parâmetros determinantes para se reconhecer uma água subterrânea de hidrogeoquímica diferenciada num aquífero, que estejam associados a um efeito medicamentoso. Ressalta-se que o item $2^{\circ}$ do Art. 36 abrange todos os intervalos possíveis de temperatura, desde fontes frias $\left(\mathrm{T}<25^{\circ} \mathrm{C}\right)$ até fontes hipertermais $\left(\mathrm{T}>38{ }^{\circ} \mathrm{C}\right)$, não constituindo um parâmetro distintivo, mas apenas descritivo de uma fonte. No caso dos elementos-traços "dignos de nota", o CAM não define precisamente todos os elementos químicos notáveis e sequer estipula suas concentrações mínimas que os associem teoricamente a algum efeito medicamentoso. Atualmente, a presença de fluoreto, lítio, vanádio, iodo e brometo em qualquer concentração (acima do limite de quantificação do equipamento de análise laboratorial) é suficiente para uma água subterrânea ser categorizada como mineral. O DNPM não leva hoje em consideração se os elementos dignos de nota estão em concentrações que signifiquem algum efeito terapêutico imediato ou uma eventual ação benéfica à saúde humana (VILLENA et al. 1996, BRANDÃO \& VALSECKI JR 1998). O DNPM, contudo, não tem corpo técnico especializado na área médica ou da saúde para definir tais parâmetros. A legislação da área de saúde e a literatura médica deveriam, neste caso, ser utilizadas para a definição de parâmetros técnicos no momento de classificar uma água mineral baseada exclusivamente em elementos-traços. BERTOLO (2006) argumenta que a presença de elementos dignos de nota poderia ser utilizada para classificação de uma água mineral somente no caso das concentrações corresponderem a dosagens nutrivas ou benéficas à saúde, conforme definidas pelo órgão competente.

Do ponto de vista geológico, ressalta-se que as fontes de água isotermal e hipertermal $(\mathrm{T}>36$ ${ }^{\circ} \mathrm{C}$ ) estão associadas geralmente a características hidrogeológicas e geoquímicas diferenciadas num aquífero, como circulação subterrânea profunda e presença de anomalias geotérmicas locais. Além do aspecto geológico, a literatura médica é quase uníssona em reconhecer os efeitos benéficos da água termal (especificamente, a hipertermal) no tratamento de algumas doenças, principalmente as reumáticas (FIORAVANTI et al. 2011), o que, em princípio, justificaria sua categorização como mineral. Neste sentido, o próprio CAM implicitamente faz referência às "águas termais" como uma categoria específica de água mineral, visto que, do Art. $5^{\circ} \mathrm{em}$ diante, há referência expressa ao grupo das águas subterrâneas reguladas pelo CAM como "água mineral, termal, gasosa, de mesa ou destinada a fins balneários" (grifo nosso).

Por fim, o princípio básico do CAM é a gestão do recurso subterrâneo por finalidade. As águas minerais e potáveis de mesa são destinadas apenas ao engarrafamento e/ou para fins balneários. Qualquer outra finalidade (abastecimento público, uso industrial, uso doméstico, irrigação, etc.), sejam as águas subterrâneas mineralizadas ou não, foge à regulação do CAM e à competência do DNPM.

\section{4 ÁGUAS MINERAIS - O SEGMENTO PRODUTIVO ATUAL}

A análise criteriosa do CAM revela alguns aspectos importantes. Primeiro, águas subterrâneas fracamente mineralizadas não estariam implicitamente associadas a algum efeito medicamentoso, portanto não deveriam ser categorizadas como minerais. Por esta razão, o CAM estipula a obrigatoriedade de testes clínicos comprobatórios dos efeitos terapêuticos e fiscalização pela CPC para as águas classificadas como oligominerais. Segundo, todas as águas subterrâneas naturalmente potáveis, em tese, são regidas pelo CAM (e pelo CM) como recursos minerais. Neste sentido, potabilidade deveria ser o parâmetro-chave para diferenciar a água subterrânea como recurso mineral ou como recurso hídrico. Terceiro, águas minerais medicinais têm um status diferenciado entre as águas subterrâneas em geral. $\mathrm{O}$ uso medicamentoso das águas 
minerais in loco, nos balneários, é a essência do CAM, ao passo que uso para engarrafamento era (na década de 1940) considerado de importância secundária, visto que algumas propriedades temporárias da água mineral, como emanação de gases radioatativos na fonte e hipertermalidade, podem ser alteradas ou perdidas com o tempo, não sendo preservadas quando a água engarrafada é disponibilizada para consumo.

Verifica-se a seguinte situação: toda água mineral e potável de mesa é necessariamente uma água subterrânea potável. No entanto, nem toda água subterrânea naturalmente potável pode ser considerada um recurso mineral, pois o CAM apenas regulamenta o uso em balneários ou para envase. A legislação de água mineral não proporciona critérios bem definidos, baseados em propriedades intrínsecas da água ou do aquífero, que permitam discriminar de forma inequívoca águas mineralizadas diferenciadas das águas subterrâneas comuns, sejam elas medicamentosas ou não. A distinção, na prática, se dá pela finalidade de uso e não devido a eventuais propriedades físico-químicas peculiares da água subterrânea.

Por outro lado, atualmente, as águas minerais não mais se distinguem das águas subterrâneas comuns, como na época em que o CAM foi promulgado. O estudo realizado por QUEIROZ (2004), sobre as características das águas minerais brasileiras (Figura 1), revela que quase metade das fontes produz águas minerais de muito baixa a baixa mineralização (resíduo seco menor que $100 \mathrm{mg} / \mathrm{L}$ ), não atingindo os parâmetros legais de composição química definidos no Art. 35 do CAM, ou são fon- tes caracterizadas como minerais exclusivamente por propriedades físico-químicas temporárias $(43 \%$ das fontes). Neste sentido, as águas minerais caracterizadas apenas por propriedades físico-químicas temporárias, como alta temperatura e presença de gases radioativos, são minerais somente nas fontes, ou próximo delas; longe de suas fontes, estas águas são apenas potáveis de mesa, pois as propriedades físico-químicas alteram-se ou são perdidas com o tempo. Há exemplos de fontes de água mineral na região Norte e Nordeste que são composicionalmente semelhantes à água de chuva (BERTOLO et al. 2007) e não possuem em sua composição química nada que as diferencie das "águas comuns". Apenas 23\% das fontes brasileiras são caracterizadas pela maior diversidade composicional da água mineral (bicarbonato, carbonato, sulfato, ferro, etc.) e estão estritamente de acordo com os limites de composição química definidos no CAM.

O segmento da água mineral no Brasil há muitas décadas deixou de ser destinado ao uso terapêutico. Atualmente, os empreendimentos são primordialmente ( $86 \%$ das fontes) voltados ao comércio de bebidas engarrafadas, ao invés de serem balneários (QUEIROZ 2004). Mesmo no caso dos balneários, perdeu-se o foco no uso medicamentoso das águas minerais e termais, que migrou para o que se conhece hoje por "termalismo recreativo", ou simplesmente, turismo de lazer. Esta mudança de foco ocorreu por dois motivos: o declínio das práticas clínicas com uso de águas minerais e termais devido à extinção da especialidade médica Crenologia (QUINTELA 2004 a, b; SERRA 2009), além da atuação intermitente da CPC como instân-
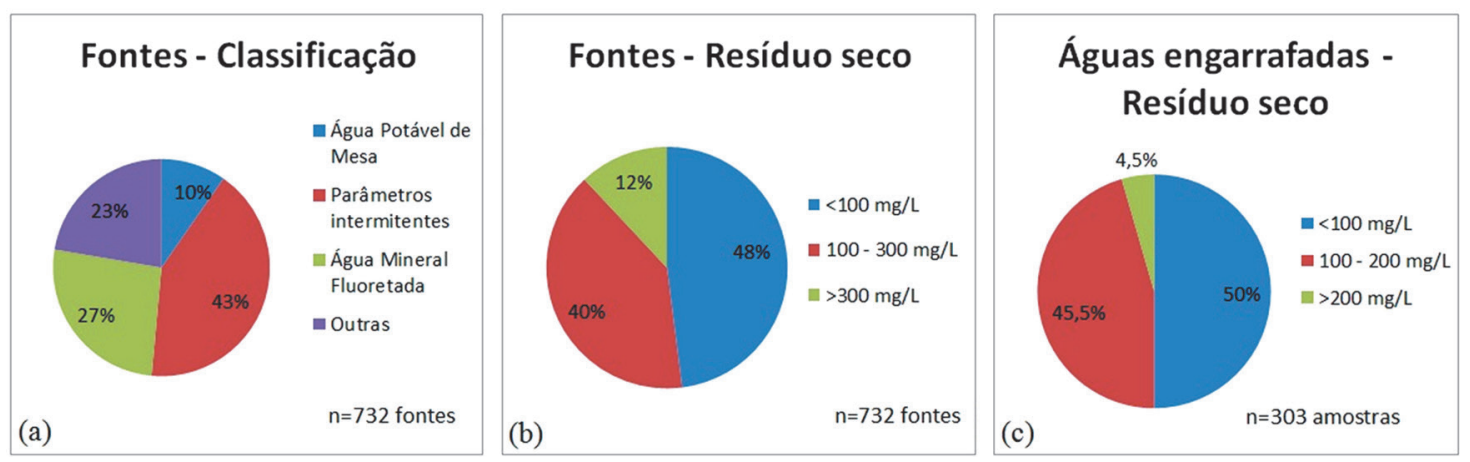

FIGURA 1 - Características das águas minerais brasileiras segundo estudos realizados por QUEIROZ (2004) e BERTOLO (2006). (a) Classificação de todas as fontes de água mineral ativas e (b) sua porcentagem de resíduo seco. Os parâmetros intermitentes referem-se às águas classificadas exclusivamente devido à radioatividade temporária da água na fonte e/ou à sua temperatura. O resíduo seco é o principal parâmetro indicativo do grau de mineralização de uma água. (c) Porcentagens de resíduo seco obtidas exclusivamente para amostras de água mineral engarrafadas disponíveis no mercado. 
cia superior técnica e fiscalizadora do uso medicamentoso das águas minerais (CAETANO 2005).

Ao mesmo tempo em que foi perdido o elo entre o segmento de água mineral e a Medicina, o setor testumunhou uma mudança radical de foco, quando a produção de água mineral engarrafada aumentou significativamente, superando em importância os balneários. A água mineral engarrafada deixou de ser vendida em farmácias, como um remédio (SERRA 2009), e se transformou em um bem de consumo doméstico extremamente popular e acessível, destinado a atender à necessidade básica do ser humano: saciar a sede. A produção de água engarrafada ocupa atualmente um papel relevante dentro do segmento industrial brasileiro, apresentando franca expansão nas últimas três décadas. As estatístiscas oficiais apontam um brusco incremento da produção de água mineral engarrafada, acima de 3 bilhões de litros a partir do ano 2000 (CAETANO 2005). A produção oficial de água mineral no Brasil atingiu cerca de 7,580 bilhões de litros em 2009, representando um valor de produção de R $\$ 1,382$ bilhão (DNPM 2010). Deste total, cerca de $70 \%$ corresponde à água mineral engarrafada, com produção de 5,324 bilhões de litros em 2009, atingindo quase 7 bilhões de litros em 2012 (DNPM 2012, 2013). Em termos de valor de produção, a água mineral supera importantes commodities minerais, como fosfato e caolim (DNPM 2010).

O mercado consumidor de água mineral engarrafada muito contribuiu para a mudança de foco deste segmento. Alguns componentes da água subterrânea que na década de 1950 eram essenciais para fins terapêuticos, como por exemplo, termalidade, moderada mineralização e conteúdo de elementos organolépticos (sulfato, ferro e bicarbonato), são atualmente irrelevantes e até mesmo indesejáveis para o consumidor de água engarrafada, porque podem imprimir algum sabor à água (PLATIKANOV et al. 2012). Por este motivo, a grande maioria da água mineral envasada no Brasil é caracterizada por baixo a baixíssimo teor de mineralização. $\mathrm{O}$ atual mercado consumidor preza basicamente a presumível pureza original da água engarrafada (KLEIN \& HUANG 2008, SERRA 2009), muito mais do que qualquer eventual efeito medicamentoso ou terapêutico que este produto possa trazer à saúde. De fato, o consumidor confia na água mineral engarrafada como um produto livre de impurezas e de contaminação (VILLENA et al. 1996), ou desconfia menos deste produto em comparação à qualidade da água de torneira, fornecida pelos serviços de abastecimento público
(WILK 2006). A pureza original da água e a proteção das fontes contra a poluição são os valores que a sociedade comumente reconhece e associa às águas minerais engarrafadas hoje em dia.

A proteção das fontes de água mineral contra a poluição (Art. 12, CAM) está regulamentada, no nível infralegal, pela Portaria DNPM 231/1998, a qual estipula a necessidade de realização, na fase exploratória, de estudos hidrogeológicos detalhados e de vulnerabilidade natural do aquífero à poluição. Segundo esta portaria, deve-se definir uma área de proteção da fonte de água mineral, subdividida em três zonas: a) zona de influência direta (perímetro imediato da fonte, em geral delimitada pelo cone de depressão do poço), b) zona de transporte (zona com fluxo subterrâneo voltado diretamente para o ponto de captação de água mineral, definida pelo tempo de trânsito que um contaminante leva para atingi-la desde a área de recarga), e c) zona de contribuição (área de recarga direta da fonte de água mineral). Segundo a norma, deve haver restrições à ocupação na área de proteção de uma fonte de água mineral que possa comprometer a qualidade da água e o aproveitamento da fonte. Em tese, qualquer intervenção subterrânea numa área de proteção deve ser previamente autorizada pelo DNPM (Art. 13, CAM). Além desta norma, a Portaria DNPM 374/2009 define critérios técnicos bastante rígidos para a construção e manutenção de uma fonte de água mineral, tanto na fase de pesquisa mineral, quanto na fase de lavra. Dentre outros inúmeros aspectos, essa Portaria determina que a fonte de água mineral deve estar inserida numa casa de proteção à captação de alvenaria, devendo ser vedada de forma eficiente à entrada de sujeira e contaminantes; a casa de proteção à captação deve ainda ser circundada com pavimento de concreto e isolada do ambiente externo por grades ou cercas. Além destes cuidados, toda a tubulação de contato com a água mineral, tanto no poço/surgência quanto na tubulação de adução, deve ser construída em aço inox ou em PVC geomecânico. Tais normas infralegais prezam pela precaução em não alterar as características originais da água mineral, quando envasada, tal qual ela se apresenta na fonte.

O conceito de pureza da água mineral (Art. 26, CAM), contudo, não está devidamente regulamentado na legislação brasileira. Isto significa que as águas minerais no Brasil devem ser potáveis, conforme exige a lei, mas não há regramento para que suas fontes estejam protegidas inequivocamente da ação de contaminantes antrópicos que tenham atingido o aquífero em concentrações abaixo dos limites considerados tóxicos ou perigosos 
à saúde. A falta de regulamentação sobre este assunto permite que hoje uma fonte de água mineral, se comprovadamente potável, possa ser aprovada mesmo se inserida dentro de uma zona comprovadamente contaminada. Por outro lado, o DNPM faz o monitoramento da qualidade das águas minerais ao longo de toda a vida útil do empreendimento, a partir da realização de análises bacteriológicas e químicas completas a cada três anos ("estudo in loco" realizado pelo Laboratório de Análises Minerais - LAMIN/CPRM). No entanto, monitora-se apenas a potabilidade das águas minerais e não há regras definidas para identificar alterações na composição original ou indícios de degradação de sua qualidade com o passar do tempo.

Cabe citar que o conceito de pureza da água mineral envasada é encontrado, por exemplo, nas normas que regem o comércio deste produto na comunidade europeia. A Diretiva 2009/54/EC, de 18/06/2009 (a qual reformulou a Diretiva 80/777/ EEC), define água mineral natural como água microbiologicamente pura, de origem subterrânea, proveniente de fontes naturais (nascentes) ou artificiais (poços), de composição estável e que seja distinta claramente da "água de beber ordinária" devido à sua composição (mineralização, oligoelementos ou outros componentes) e sua pureza original. Segundo a diretiva europeia, é imperativo que as fontes estejam intactas e protegidas de qualquer risco de poluição, aspecto que é relevante do ponto de vista de proteção da saúde pública. Para a comunidade europeia, há uma diferença clara entre água mineral engarrafada, que é considerada um bem de consumo humano (alimento), e águas utilizadas como produtos medicinais (medicinal products), de uso terapêutico em balneários e spas, estes últimos regulamentados separadamente, através da Diretiva 2001/83/EC.

Não há diferenciação na legislação brasileira entre água engarrafada e recurso terapêutico, ou seja, entre água mineral para produção de alimento e água mineral para uso medicamentoso, respectivamente, como ocorre na Comunidade Europeia. Para esta, recurso terapêutico é assunto afeto primordialmente à área de Medicina e não se confunde com a indústria de bens de consumo, como é o caso da água envasada. No Brasil, conforme os dispositivos legais do CAM, estes dois conceitos estão fundidos em um só, pois água envasada é teoricamente uma água medicamentosa, sob a responsabilidade gerencial de uma instituição (o DNPM) cujo corpo técnico é formado basicamente por geólogos e engenheiros de minas, os quais não possuem conhecimento técnico nem atribuição profissional na área de produção de alimentos e muito menos na área de Saúde.

\section{PRINCÍPIOS CONSTITUCIONAIS PARA O APROVEITAMENTO DOS RECURSOS MINERAIS E HIIDRICOS}

A Constituição Federal de 1988 não faz menção expressa às águas minerais e não especifica que estas seriam exceção dentro do contexto das águas subterrâneas ou dos recursos minerais. Se o constituinte quisesse excluir as águas minerais dos recursos minerais, deveria ter feito de forma expressa no texto constitucional, o que não ocorre. Da mesma forma, se o constituinte entendesse que as águas minerais deveriam ser diferenciadas das águas subterrâneas, deveria tê-lo feito expressamente, à semelhança da exceção dada aos potenciais de energia elétrica (Art. 26, I CF). Infere-se, portanto, que no processo de elaboração da Constituição Federal de 1988 não foi levada em consideração a vigência do CAM, que contempla a água mineral como recurso mineral em nível infraconstitucional, diferenciando-a dos recursos hídricos. A água mineral não é um mineral em termos conceituais (Mineralogia), mas é um minério do ponto de vista legal.

A Constituição Federal considera os recursos minerais como bens patrimoniais da União (Art. 20, IX, CF), e define que é competência privativa da União legislar sobre esta matéria (Art. 22, XII, $\mathrm{CF}$ ). Com relação ao aproveitamento econômico dos recursos minerais, a Constituição de 1988 trata-o especifica e detalhadamente dentro do capítulo sobre a Ordem Econômica e Financeira. O Art. 176 elucida diversos princípios da atividade de mineração: a) a dualidade jurídica entre a propriedade do solo (que pode ser privada ou não) e a propriedade dos recursos minerais (exclusivamente da União); b) a propriedade do produto da lavra garantido ao concessionário de direito minerário; c) o regime de aproveitamento dos recursos minerais (autorização ou concessão federal); d) o direito de participação do superficiário nos resultados das operações de lavra; e) a necessidade de anuência prévia do poder concedente no processo de transferência dos direitos minerários; f) a obrigatoriedade da atividade de mineração atender ao interesse nacional; g) a definição dos titulares de direitos minerários, que são brasileiros ou empresas constituídas sob as leis brasileiras, com sede e administração em território nacional; e h) as condições especiais da atividade de mineração na zona de fronteira. Cabe ressaltar também que o minerador tem a obrigação constitu- 
cional de recuperar as áreas degradadas pela atividade de mineração (Art. 225, $\S 2^{\circ}, \mathrm{CF}$ ).

Os princípios constitucionais preponderantes que regem o aproveitamento dos recursos minerais residem na supremacia do interesse público sobre o privado (SERRA 2000, HERRMANN 2007, TRINDADE 2009) e na condução da atividade de mineração conforme o interesse nacional. Neste sentido, apesar da atividade de mineração no Brasil ser exercida exclusivamente por empresas privadas, a atividade deve atender aos interesses maiores da coletividade e não apenas focar nos interesses individuais e geração de lucro. Isto significa que a produção de bens minerais atende aos anseios da coletividade do ponto de vista do fornecimento de matérias primas minerais para uma vasta indústria de transformação (siderurgia, metalurgia, química, tecnológica, etc.) e de produção de bens de consumo, assim como abastece um mercado doméstico em franca expansão, nos pequenos e nos grandes centros urbanos, responsáveis por obras de infraestrutura de todos os tipos, que trazem conforto à sociedade e desenvolvimento ao país.

Quando a extração dos recursos minerais é devidamente autorizada, a propriedade do produto mineral é assegurada ao concessionário do direito de lavra. Desta forma, o título de lavra é o instrumento legal a partir do qual a propriedade de um bem público (recurso mineral in situ) é transferida para uma entidade privada (concessionário), após o recurso ter sido explotado, deixando de integrar a esfera pública (TRINDADE 2009, 2011). TRINDADE (2009) argumenta ainda que o interesse público no aproveitamento econômico dos recursos minerais deve ser resguardado pelo exercício da função social da propriedade mineral, representada pelo aproveitamento eficiente e racional de recursos não-renováveis. Segundo esta linha de raciocínio, o minerador possui a obrigação de dar a melhor destinação ao produto mineral sob o ponto de vista técnico, econômico, social e ambiental, visando o benefício da sociedade como um todo, em retribuição ao direito de propriedade adquirido sobre um bem público (TRINDADE 2009).

A Constituição Federal, por outro lado, foi promulgada em consonância aos princípios de proteção do meio ambiente e de sustentabilidade difundidos em nível internacional (Art. 225, CF). Os princípios ambientais contemplados na Constituição promoveram uma mudança de paradigma na forma como a sociedade passou a lidar com os recursos naturais. Importante parcela destes recursos foi constitucionalmente categorizada como bens ambientais, ou recursos ambientais. Os bens am- bientais são considerados bens de domínio público e de uso comum do povo, que englobam todos os elementos do ecossistema necessários para manter o "meio ambiente ecologicamente equilibrado, essencial à sadia qualidade de vida" (Art. 225, CF). As águas, em geral, em conjunto com a atmosfera, o solo, o subsolo, os estuários, o mar territorial, a fauna, a flora, e demais elementos da biosfera (Art. 3, V, Lei 6.938/1981), constituem bens ambientais, ou seja, bens públicos inalienáveis. O poder público e a coletividade compartilham a responsabilidade constitucional de defender e preservar os recursos ambientais para as atuais e futuras gerações (Art. 225, CF).

A Constituição Federal estabelece, portanto, que as águas são bens de domínio público, não mais existindo águas de propriedade particular, ao contrário do previsto no Código de Águas de 1934. As águas superficiais estão sob o domínio da União ou dos Estados, dependendo da situação geográfica dos corpos d'água. Corpos d'água doce superficiais que banhem mais de um Estado ou que sejam limítrofes com outros países são de dominialidade da União (Art. 20, III, CF); o restante encontra-se sob a jurisdição dos Estados. As águas subterrâneas, por sua vez, estão inseridas exclusivamente entre os bens dos Estados (Art. 26, I, CF). A Carta Magna não aborda especificamente o aproveitamento econômico das águas, mas previu a criação de um sistema nacional de gerenciamento de recursos hídricos, com definição dos critérios gerais para a outorga de direitos de seu uso (Art. 21, XIX, CF).

Visando regulamentar o Art. 21, XIX da Constituição, foi promulgada a Lei das Águas (Lei 9.433/1997), que instituiu a Política Nacional de Recursos Hídricos (PNRH) e trouxe uma abordagem moderna e inovadora de gestão descentralizada e participativa da água, baseada na articulação do poder público com os usuários e as comunidades. A Lei das Águas criou o Sistema Nacional de Gerenciamento de Recursos Hídricos (SINGREH) e introduziu novos intrumentos de gerenciamento, como por exemplo, os planos de recursos hídricos, a outorga (estadual e federal) de uso de recursos hídricos e a cobrança pelo seu uso. A PNRH reconhece a água como um recurso finito, vulnerável e dotado de valor econômico, cuja gestão é descentralizada nas diversas bacias hidrográficas e prioriza o uso múltiplo das águas (Art. $1^{\circ}$, Lei 9.433/1997). Os objetivos da PNRH estão em consonância com os pilares do desenvolvimento sustentável, ou seja, o uso racional dos recursos hídricos e o aproveitamento econômico contingente com a sua disponibilidade em quantidade e quali- 
dade adequadas para as atuais e futuras gerações (Art. 20 Lei 9.433/1997).

Os princípios constitucionais em relação ao meio ambiente, combinados aos fundamentos da Política Nacional de Meio Ambiente (Art. 3, V, Lei 6.938/1981) e do Código Civil Brasileiro (Art. 99, Lei 10.046/2002), atribuem solidamente uma dimensão ambiental às águas em geral, incluindo a água subterrânea (CASSUTO \& SAMPAIO 2011). A água subterrânea, enquanto recurso ambiental, é um bem de domínio público e de uso comum do povo, de caráter não dominical e não alienável. Bens públicos de uso comum são insusceptíveis do direito de propriedade, mas a Constituição designa o titular da relação jurídica ao qual confia a guarda e gestão destes bens (POMPEU 2010). Assim, o poder público (União ou Estados) não é proprietário das águas no sentido dominial, mas o seu gestor no interesse coletivo e no aspecto tutelar (LEME MACHADO 2002). O uso comum ou privativo de bens ambientais depende, portanto, de outorga de uso por parte do poder concedente que detém o domínio deste recurso, sob a premissa de atendimento do interesse público e o benefício da coletividade (DI PIETRO 2010).

A tabela 2 apresenta um cenário comparativo dos princípios constitucionais quanto aos recursos minerais e águas. A principal distinção entre estes recursos refere-se à sua categorização como bens públicos e à respectiva dominialidade. Recursos minerais são bens públicos dominicais da União e as águas subterrâneas, especificamente, são bens públicos de uso comum do povo, sob a jurisdição dos Estados, os quais adquirem também a categoria de recursos ambientais a serem preservados para as futuras gerações. Esta diferença não traria maiores consequências se dentre os recursos minerais não constasse a água mineral. A principal origem do conflito entre os setores de mineração e de recursos hídricos está, portanto, na Constituição. Ou melhor, está na recepção pela Constituição dos dispositivos legais infraconstitucionais relativos à água mineral que antecedem a Carta Magna.

TABELA 2 - Tratamento constitucional dispensado às águas e aos recursos minerais.

\begin{tabular}{|c|c|c|}
\hline Princípios Constitucionais & Recursos Minerais & Águas e Recursos Hidricos \\
\hline Categoria de bem & Bens públicos dominicais (alienável) & $\begin{array}{l}\text { Bens públicos de uso comum do povo } \\
\text { (inalienável) }\end{array}$ \\
\hline \multirow{3}{*}{ Domínio } & \multirow{3}{*}{ União, exclusivamente } & União ou Estados (águas superficiais) \\
\hline & & $\begin{array}{l}\text { Estados, exclusivamente (água } \\
\text { subterrânea) }\end{array}$ \\
\hline & & $\begin{array}{l}\text { União, exclusivamente (potencial } \\
\text { hidrelétrico) }\end{array}$ \\
\hline \multirow[t]{2}{*}{ Aproveitamento econômico } & \multirow[t]{2}{*}{ Autorização e concessão federal } & $\begin{array}{c}\text { Outorga de direito de uso de recursos } \\
\text { hídricos (Autorização federal ou } \\
\text { estadual) }\end{array}$ \\
\hline & & $\begin{array}{l}\text { (Autorização estadual para água } \\
\text { subterrânea) }\end{array}$ \\
\hline
\end{tabular}

Atividade de mineração deve atender ao interesse nacional

$\begin{array}{lll} & & \begin{array}{c}\text { Criação de sistema nacional de } \\ \text { gutros aspectos }\end{array} \text { Propriamedade privada do bem minerado }\end{array}$

Recuperação de áreas degradadas pela atividade de mineração

Águas como bens ambientais 


\section{CONFLITOS DE COMPETÊNCIA NA GESTÃO DAS ÁGUAS MINERAIS E DOS RECURSOS HÍDRICOS}

Com a gestão das águas minerais pelo DNPM, paralelamente à gestão dos recursos hídricos pelos órgãos competentes estaduais e federais, criou-se uma situação inusitada. Após a publicação da Lei das Águas (Lei 9.433/1997), passam a existir três categorias legais de águas subterrâneas no Brasil: as águas minerais e potáveis de mesa, tratadas juridicamente como recursos minerais, e as águas subterrâneas comuns, geridas como recursos hídricos no âmbito da PNRH. Diferentes categorias de água subterrânea estão associadas a distintas jurisdições, conceitos legais e estilos de gerenciamento, conforme pode ser visualizado na tabela 3. Esta diferenciação jurídica não se reflete na prática, uma vez que o recurso geológico é um só: a água subterrânea naturalmente potável e mineralizada. A sobreposição de competências sobre um mesmo recurso ocorre devido ao silêncio do texto constitucional em relação à água mineral, conforme descrito no item anterior, e ao silêncio da Lei 9.433/1997. Esta última não aborda expressamente a água mineral no escopo da PNRH, nem como situação de exceção, como por exemplo é dada aos potenciais hidrelétricos. O Art. 12 da Lei 9.433/1997 relaciona as situações que demandam outorga de uso de recursos hídricos. Em seu $\S 1^{\circ}$ constam os usos dispensados de outorga (não constam as águas minerais) e o $\$ 2^{\circ}$ trata dos potenciais de energia elétrica, que possuem legislação setorial específica e jurisdição federal, mas ficam subordinados à PNRH. As águas minerais não são citadas expressamente na lei, no entanto poderiam perfeitamente ser enquadradas tanto no inciso II

TABELA 3 - Análise comparativa das categorias legais de água subterrânea.

\begin{tabular}{|c|c|c|}
\hline Aspectos jurídicos & Água subterrânea como recurso mineral & Água subterrânea como recurso hídrico \\
\hline Arcabouço legal & CAM, CM & $\begin{array}{c}\text { Lei das Águas, leis estaduais de gestão } \\
\text { de RH }\end{array}$ \\
\hline Categorias & $\begin{array}{c}\text { Águas minerais (1.s.), Água potável de } \\
\text { mesa }\end{array}$ & $\begin{array}{c}\text { Água subterrânea comum (composição } \\
\text { normal) }\end{array}$ \\
\hline Tipo de bem público & $\begin{array}{l}\text { Bem público dominical da União } \\
\text { (alienável) }\end{array}$ & $\begin{array}{l}\text { Bem público de uso comum do povo } \\
\text { (inalienável) }\end{array}$ \\
\hline Jurisdição & Federal, exclusivamente & Estadual, exclusivamente \\
\hline Conceitos & $\begin{array}{l}\text { Água subterrânea naturalmente potável, } \\
\text { com ação medicamentosa ou não }\end{array}$ & $\begin{array}{l}\text { Água subterrânea cujo uso depende do } \\
\text { tipo de enquadramento do aquífero }\end{array}$ \\
\hline $\begin{array}{c}\text { Princípios do } \\
\text { aproveitamento econômico }\end{array}$ & $\begin{array}{c}\text { Direito de prioridade, lavra até a exaustão } \\
\text { da jazida, propriedade privada do produto } \\
\text { da lavra, recuperação de áreas degradadas, } \\
\text { proteção das fontes contra poluição }\end{array}$ & $\begin{array}{l}\text { Uso racional, uso múltiplo da água } \\
\text { subterrânea, disponibilidade hídrica do } \\
\text { aquífero, vazão de explotação sustentável, } \\
\text { proteção das fontes contra poluição }\end{array}$ \\
\hline \multirow{2}{*}{$\begin{array}{l}\text { Regime jurídico para } \\
\text { aproveitamento econômico }\end{array}$} & $\begin{array}{l}\text { Concessão de lavra (validade } \\
\text { indeterminada) }\end{array}$ & $\begin{array}{l}\text { Autorização de uso de RH (validade } \\
\text { máxima de } 35 \text { anos) }\end{array}$ \\
\hline & $\begin{array}{l}\text { Direito de propriedade sobre o recurso } \\
\text { subterrâneo explotado (com apropriação } \\
\text { legal do recurso subterrâneo) }\end{array}$ & $\begin{array}{l}\text { Direito de uso do recurso hídrico } \\
\text { explotado (sem apropriação legal do } \\
\text { recurso subterrâneo) }\end{array}$ \\
\hline \multirow{4}{*}{ Gestão } & DNPM (Sede e superintendências) & $\begin{array}{c}\text { Órgãos estaduais de recursos hídricos } \\
\text { (SINGREH) }\end{array}$ \\
\hline & $\begin{array}{c}\text { Gestão por finalidade (envase e } \\
\text { balneoterapia) no âmbito do CAM }\end{array}$ & $\begin{array}{l}\text { Gestão por finalidade (uso múltiplo das } \\
\text { águas) no âmbito da PNRH }\end{array}$ \\
\hline & Unidade de gestão: poligonal minerária & Unidade de gestão: bacia hidrográfica \\
\hline & Não integrada à PNRH & Integrada à PNRH \\
\hline
\end{tabular}

CAM - Código de Águas Minerais, CM - Código de Mineração, PNRH - Política Nacional de Recursos Hídricos, RH - recursos hídricos, SINGREH - Sistema Nacional de Gerenciamento de Recursos Hídricos. 
("extração de aquifero subterrâneo para consumo final ou insumo de processo produtivo"), quanto no inciso V ("outros usos que alterem o regime, a quantidade ou a qualidade da água existente em um corpo d'água") do Art. 12. Adicionalmente, o Art. $4^{\circ}$ instiga a colaboração entre os entes federados (União e Estados) tendo em vista o gerenciamento dos recursos hídricos de interesse comum.

Desta forma, o entendimento jurídico comum é que, dependendo da finalidade de uso, a água subterrânea será gerida ora pelo órgão federal (DNPM), no âmbito do CAM, ora pelos órgãos estaduais de recursos hídricos, no âmbito da PNRH e das respectivas legislações estaduais. Se há destinação para engarrafamento e para fins balneários, a água subterrânea será gerida como recurso mineral; qualquer outro uso, a mesma será gerida como recurso hídrico subterrâneo. Em tese, o CAM regulamenta o aproveitamento de águas subterrâneas peculiares, especiais, distintas das águas comuns. Conforme discutido no item 4 , essa premissa não mais se aplica à realidade brasileira do mercado produtor de água minerais, nem na teoria, nem na prática.

A divisão de competências conforme a finalidade do uso da água subterrânea funciona razoavelmente bem. $\mathrm{O}$ problema reside nas situações onde há interesses conflitantes no uso do mesmo recurso subterrâneo por diferentes setores econômicos numa região. Toma-se o exemplo da situação de conflito verificada em Caldas Novas e Rio Quente, em Goiás, reportada no trabalho ANDRADE \& ALMEIDA (2012), entre a gestão dos empreendimentos balneários pelo DNPM e o serviço municipal de abastecimento público de Caldas Novas. Situações de conflito de interesses sobre o uso de recursos hídricos subterrâneos não raramente vão parar nos tribunais, como no caso de Caldas Novas (ANDRADE \& ALMEIDA 2012), mas também suscitam muitas vezes grande polêmica junto à população. É o caso, por exemplo, do Parque das Águas, em São Lourenço, MG, atualmente sob administração da Nestlé Waters Brasil, a qual foi acusada pela população local de superexplotar o aquífero e exaurir fontes centenárias de águas magnesianas e alcalinas do referido parque (ver reportagem disponível em http://www.apublica. org/2014/04/em-guerra-contra-a-nestle/). Segundo GUIMARÃES (2009), a Nestlé em São Lourenço tem priorizado a produção de água mineral engarrafada, numa escala de produção crescente desde que assumiu, em 1996, os direitos minerários associados ao Parque das Águas dessa cidade, em detrimento da manutenção das fontes e fontanários seculares ali presentes, renomados em vir- tude de suas propriedades medicinais. Este autor argumenta que o crescimento da produção de água engarrafada é uma tendência mundial, mas no Brasil o mesmo é sustentado na "privatização" de bens públicos, cujo objetivo é predominantemente econômico e não entende a água mineral nem como recurso hídrico nem como bem ambiental.

Ciente das situações de conflito de interesses entre a gestão dos recursos hídricos (água subterrânea) e a dos recursos minerais (águas minerais e água potável de mesa), o Conselho Nacional de Recursos Hídricos (CNRH), no âmbito da sua Câmara Técnica de Águas Subterrâneas (CTAS), promoveu uma longa discussão a partir de 2002, visando promover efetivamente a integração da gestão das águas minerais com a dos recursos hídricos, dentro do Sistema Nacional de Gerenciamento de Recursos Hídricos (SINGREH), que segue as diretrizes da PNRH. A discussão na CTAS foi intensificada em 2004, com a realização de um seminário entre os representantes dos setores de mineração e de recursos hídricos. O artigo de REIS (2005) traz detalhadamente o histórico de discussão deste assunto no CTAS/CNRH. O objetivo maior da CTAS era elaborar uma resolução que regulamentasse a integração dos empreendimentos de água mineral aos sistemas estaduais de outorga de recursos hídricos (REIS 2005, CAETANO 2005). Contudo, não houve consenso entre os membros da Câmara por resistência dos representantes do próprio DNPM e da Confederação Nacional da Indústria, que entederam a outorga de uso de recursos hídricos para água mineral como invasão da competência federal (REIS 2005, SCALON 2011). Em 2007, finalmente, foi publicada a Resolução CNRH 76/2007, que contém diretrizes para favorecer o diálogo entre os órgãos gestores estaduais (recursos hídricos) e o órgão federal (DNPM), visando estimular a troca de informação de dados técnicos e dos repectivos sistemas de outorga. No âmbito do DNPM, as diretrizes da Resolução CNRH 76/2007 ainda não foram formal e uniformemente implementadas nas suas unidades descentralizadas.

\section{REFLEXÕES SOBRE A CONSTITUCIONALIDADE DO CAM}

Uma análise sobre a recepção dos dispositivos legais do CAM pela Constituição de 1988 merece ser abordada. O primeiro ponto refere-se à categorização das águas minerais e da água subterrânea como bens públicos. Águas minerais e potáveis de mesa são consideradas recursos minerais 
no nível infraconstitucional, os quais constituem bens dominicais da União, ao passo que as águas subterrâneas estão inseridas constitucionalmente sob o domínio dos Estados, consideradas bens de domínio público e de uso comum do povo. A diferença entre elas reside no princípio da inalienabilidade destas últimas. A legislação afeta aos recursos minerais tem por princípio a transferência da propriedade de um bem público (recurso mineral in situ) das mãos da União para as da entidade privada (recurso mineral lavrado), neste caso, o concessionário de direito de lavra. Este princípio vale para a água mineral. Isto significa que, legalmente, o concessionário de direito de lavra tem direito possessório sobre a água mineral extraída do subsolo. Este aspecto conflita diretamente com os princípios gerais que norteiam a gestão dos recursos hídricos no âmbito da PNRH. O uso privativo dos recursos hídricos, a partir dos sistemas estaduais de outorga de direitos, não representa direito real de propriedade sobre a água subterrânea, mas apenas o direito de uso de um bem público, sendo que o bem público se mantém na esfera pública (POMPEU 2010). Desta forma, o regime jurídico aplicável ao aproveitamento econômico das águas minerais e potáveis de mesa é incoerente com o princípio constitucional e infraconstitucional que designa as águas subterrâneas como bens públicos de uso comum do povo, pois o CAM permite, em tese, a incorporação da água mineral extraída ao patrimônio particular do concessionário.

A segunda preocupação reside na categorização da água potável de mesa como recurso mineral, sob o domínio da União. Tecnicamente, água potável de mesa é o mesmo que água subterrânea comum e não há justificativas geológicas nem jurídicas para mantê-la com status de recurso mineral. Cabe lembrar que na década de 1940, quando o CAM foi promulgado, não havia política instituída em nível federal ou estadual para gestão da água subterrânea como recurso hídrico e o CAM não conflitava com a Constituição de 1937, vigente à época, nem com o Código de Águas de 1934. No entanto, considerando os princípios legais e instrumentos para aproveitamento econômico de águas subterrâneas que passaram a vigorar com a publicação da Lei das Águas, pode-se argumentar que a categoria água potável de mesa teria sido revogada pela Constituição de 1988. Água potável de mesa representa de fato água subterrânea comum, incluída na jurisdição estadual como recurso hídrico subterrâneo. Nossa opinião é que o DNPM/MME deveria suspender a outorga de direitos minerários para água potável de mesa por conflitar diretamen- te com o Art. 26 da Constituição Federal.

Por fim, o terceiro aspecto refere-se à leitura atenta do próprio Art. 26 da Constituição Federal, que inclui as águas subterrâneas entre os bens dos Estados. Como a Constituição não faz qualquer exceção expressa às águas subterrâneas, em tese, as mineralizadas estariam também inseridas na jurisdição estadual. Considerando a supremacia da norma constitucional, águas minerais não deveriam mais ser consideradas bens dominicais da União, de forma que o CAM como um todo teria sido revogado pela Constituição de 1988 (SERRA 2009). Ao deixar a esfera federal, as águas subterrâneas potáveis e mineralizadas passariam a integrar a jurisdição estadual simplesmente como recursos hídricos subterrâneos, conforme tese defendida por SERRA (2009).

É muito difícil resgatar a intenção do legislador constituinte. Havia interesse de incluir as águas mineralizadas entre os bens dos Estados ou simplesmente os dispositivos legais do CAM foram esquecidos no processo de elaboração da Constituição? Se o CAM foi de fato esquecido, caberia propor uma emenda constitucional ao Art. 26 da CF? Como aventar a possiblidade de emenda ao Art. 26 sem considerar a incompatibilidade do regime jurídico minerário para as águas minerais, que não atende à dimensão ambiental das águas subterrâneas como bens públicos de uso comum do povo?

É sabido que o controle de constitucionalidade de leis que antecedem a Constituição de 1988 é matéria polêmica e de difícil consenso. A princípio, este controle é exercido pelo Supremo Tribunal Federal (STF) de forma incidental (indiretamente, através da via recursal, em litígios judiciais que atingem aquela instância máxima) ou principal (ação diretamente apresentada ao STF), neste último caso a partir da Arguição de Descumprimento de Preceito Fundamental (ADPF). A constitucionalidade do CAM nunca foi questionada formalmente perante o STF. Se o fosse, a decisão jurídica poderia trazer mudanças radicais para o segmento da indústria de água mineral, caso o entendimento daquela Corte seguisse a leitura atenta do Art. 26 da Constituição, conforme tese defendida por SERRA (2009).

Por outro lado, mudanças no estilo de gestão das águas minerais para um modelo mais em sintonia com o meio ambiente e o desenvolvimento sustentável possivelmente poderiam evitar conflitos e disputas judiciais. Conforme argumentam GUIMARÃES (2009) e FERREIRA JUNIOR (2011), o CAM merece ser reinterpretado à luz dos valores ambientais contidos na Constituição de 1988 e dos 
novos instrumentos de gestão por ela introduzidos com relação aos recursos ambientais e hídricos. O ajuste da gestão das águas minerais às novas regras é essencial para que o CAM tenha sido recepcionado pela Constituição de 1988 (FERREIRA JUNIOR 2011).

\section{NECESSIDADE DE REVISÃO DO CÓDIGO DE ÁGUAS MINERAIS}

O segmento da água mineral brasileira sofre hoje uma "crise de identidade" em comparação à época em que o CAM foi promulgado, pois os empreendimentos não mais estão voltados ao uso terapêutico das águas em balneários, e sim ao engarrafamento. Atualmente, as fontes de águas minerais, com algumas exceções, quase não mais se diferenciam das águas subterrâneas comuns, ou seja, aquelas de composição ordinária. A potabilidade não é mais parâmetro-chave para diferenciar as águas regidas pelo CAM daquelas consideradas recursos hídricos, e sim a finalidade do seu uso. A gestão das águas minerais pelo seu uso não é princípio nem instrumento da gestão dos recursos minerais, mas sim da gestão de recursos hídricos pela PNRH. A gestão das águas minerais não está atualmente integrada à gestão dos recursos hídricos por falha da legislação (silêncio dos dipositivos da PNRH e desatualização do CAM) e por falta de colaboração entre instituições federais e estaduais. Por fim, para o atual mercado consumidor de águas engarrafadas, é irrelevante o fato da água subterrânea possuir eventuais efeitos benéficos à saúde. A única questão que realmente importa é a qualidade da água para consumo final e as características que agradam o paladar e favorecem a dessedentação. Verifica-se, portanto, que os conceitos originais do CAM (água com uso terapêutico) perderam eficácia com o tempo (SERRA 2009), pois foram modificados profundamente por novos valores consuetudinários (a pureza original da água mineral e proteção de suas fontes à poluição) e pela evolução dos conceitos e instrumentos de gestão dos recursos ambientais e hídricos no Brasil.

Cabe ressaltar que na época que o CAM foi promulgado, pouco se conhecia sobre a dinâmica da água subterrânea no subsolo. Os conceitos modernos de Hidrogeologia começaram a ser difundidos a partir da década de 1960 no Brasil. Não é incomum encontrar referências equivocadas na literatura de que a origem da água mineral seria principalmente juvenil ou magmática (MOURÃO 1992), dissociada, portanto, das águas superficiais e do ciclo hidrológico. De acordo com o Prof. ALDO REBOUÇAS (2006), é amplamente aceito e divulgado que $97 \%$ de toda água subterrânea disponível no planeta seja de origem meteórica, cuja recarga se deu por infiltração de águas superficiais em algum momento do tempo geológico; águas subterrâneas juvenis ou de formação constituem apenas 3\% deste total. Neste sentido, é compreensível que as águas subterrâneas fossem antes consideradas especiais, cuja natureza as aproximavam mais dos recursos minerais do que dos recursos hídricos superficiais (SERRA 2009). Os recursos hídricos superficiais, na década de 1940, eram geridos basicamente para a finalidade de geração de energia elétrica, sob a égide do Código de Águas de 1934, e não havia regramento para gestão de recursos hídricos subterrâneos, apenas para os mineralizados, no âmbito do CAM. Aí reside a origem da gestão isolada das águas minerais e potáveis de mesa pelo DNPM, pois não se exercia integradamente a gestão dos recursos hídricos superficiais e subterrâneos, em nível nacional, antes do final da década de 1990.

Juridicamente, a gestão das águas minerais não deveria ser diferenciada nem isolada dos recursos hídricos, tendo em vista a dimensão ambiental da água. Geologicamente, é inconcebível a gestão individualizada da água subterrânea, seja ela mineralizada ou não, sem considerar a disponibilidade hídrica do sistema aquífero ou sem considerar a integração do recurso subterrâneo ao superficial, como parte do ciclo hidrológico. Os princípios que regem a gestão dos recursos hídricos, em nível nacional e estadual, deveriam também ser aplicados e integrados à gestão das águas minerais, por superveniência das legislações ambiental e de recursos hídricos promulgadas a partir da década de 1980 .

Do ponto de vista técnico-científico, vários aspectos hidrogeoquímicos do CAM estão desatualizados e merecem revisão. Os trabalhos de BERTOLO (2006) e BERTOLO et al. (2007) abordam detalhadamente este assunto. Merecem destaque os seguintes parâmetros de classificação da água mineral: a) radioatividade temporária ou permanente, que é considerada benéfica no tratamento de alguns males à saúde pela Crenologia (MOURÃO 1992, NASERMOADDELI \& KAGAMIMORI 2005 e VACCAREZZA \& VITALE 2010), mas também particularmente perigosa em ambientes fechados, devido à exposição em doses baixas ou moderadas de radionuclídeos (WHO 2011); b) presença de elementos-traços, ou dignos de nota, uma vez que não há regulamentação por parte do DNPM ou da área da Saúde que os definam, bem como suas res- 
pectivas concentrações, associados a propriedades benéficas para consumo humano; c) o fato do CAM admitir a presença na água mineral de elementos tóxicos ou potencialmente perigosos à saúde, como $\mathrm{o}$ arsênio e o nitrato.

A vigência do CAM em sua forma original, sem nunca ter sido atualizado, tem proporcionado uma grande confusão institucional, ainda hoje difícil de resolver. Primeiro, o CAM alterou a natureza de um recurso natural, no caso a água subterrânea, que deixou de ser simplesmente "água", mas legalmente foi atribuída ao patrimônio da União com status de bem mineral; um minério da mesma forma que o ouro, o ferro e o calcário. Segundo, o CAM definiu originalmente as águas minerais em função da sua ação medicamentosa. Conforme apontado por MOURÃO (1992), água mineral é um "assunto de nível médico". Considerando o interesse original do uso das águas minerais para a Medicina, o legislador cometeu um equívoco histórico ao atribuir a gestão das águas minerais ao DNPM, um órgão composto por técnicos sem nenhuma formação profissional qualificada na área médica e de saúde. Terceiro, com o declínio das práticas crenoterápicas, substituídas pela produção crescente de água engarrafada, houve uma mudança na forma de interpretar a lei diante deste novo cenário. Neste sentido, os parâmetros de potabilidade passaram a ser determinantes na classificação de uma água mineral, muito mais do que reconhecer uma água de composição diferenciada e estável em relação às "águas comuns". Além disto, o DNPM passou a gerir as águas minerais necessariamente em função da finalidade (basicamente o engarrafamento), visando compatibilizar a competência do DNPM aos novos princípios e diretrizes legais introduzidas pela Constituição e pela PNRH à gestão dos recursos hídricos subterrâneos.

O conceito básico do CAM, que define águas minerais como aquelas que possuem ação medicamentosa, está em desuso. Neste sentido, vale ressaltar as palavras de MIGUEL REALE (2001, p. 107), de que a "regra de direito deve (...) ser formalmente válida e socialmente eficaz" (grifos nossos). Quando a norma jurídica cai em efetivo desuso é porque perdeu eficácia, ou seja, deixou de haver correspondência dos comportamentos sociais com o seu conteúdo original (REALE 2001). Para evitar o divórcio entre a realidade social e a norma de direito, cabe ao poder público promover o reajustamento permanente da lei aos valores e legítimos interesses da sociedade (REALE 2000).

O marco legal das águas minerais merece ser revisado à luz da Constituição Federal de 1988, que introduziu a dimensão ambiental para a água subterrânea e atribuiu aos Estados a competência para gerir tais recursos segundo as diretrizes de gestão descentralizada e participativa da PNRH. O momento político atual é favorável para retomar uma discussão no âmbito governamental visando à atualização do CAM, tendo em vista que um novo marco legal da mineração está em tramitação no Congresso Nacional desde junho/2013 (Projeto de Lei 5.807/2013). A nova lei para o setor de mineração deverá introduzir novos princípios e intrumentos de regulação dos recursos minerais, sem, no entanto, modificar o estilo de gerenciamento das águas minerais. Defendemos que a atualização da legislação afeta às águas minerais é necessária e urgente, mas deveria envolver ampla discussão entre os diversos setores da sociedade com interesses conflitantes nesta matéria.

Não se trata apenas de atualizar a lei. Houve três grupos de trabalhos formados no DNPM para discutir a atualização do CAM, em 1980, 1985 e 2002, que não foram frutíferos, pois a discussão nunca ultrapassou a barreira institucional (SERRA 2009). A discussão em torno de uma nova legislação para as águas minerais deve ser conduzida em debate franco e aberto sobre qual é o modelo de gestão deste recurso que a sociedade deseja. Este processo poderá envolver, por exemplo, a definição de novos princípios, fundamentos e instrumentos, eventualmente distintos daqueles atualmente vigentes, os quais devem ser norteados pelos princípios constitucionais que atribuem à água uma dimensão ambiental. É devido à dimensão ambiental da água subterrênea que este processo merece o crivo democrático e participativo da sociedade como um todo.

\section{CONCLUSÕES}

Nas primeiras décadas de vigência do Código de Águas Minerais de 1945 (CAM), o uso das águas minerais estava diretamente ligado a práticas médicas em balneários e estâncias hidrominerais e estas eram caracterizadas por composição química diferenciada e por propriedades físico-químicas peculiares, de presumível ação medicamentosa imediata. Este cenário mudou progressivamente ao longo do tempo, com declínio da popularidade dos balneários ao mesmo tempo em que houve a "commoditização" das águas minerais, devido ao incremento espetacular da produção de águas engarrafadas. As águas moderadamente mineralizadas, termais, sulfurosas e carbogasosas deram lugar à água de beber 
"leve", de composição ordinária, de baixa a baixíssima mineralização, mas de grande aceitação no mercado consumidor de bebidas engarrafadas. Esta mudança de valores não teve reflexo algum na norma de direito, pois o CAM continua em vigor sem nunca ter sido emendado. Alguns conceitos originais da lei continuam válidos, outros não. No entanto, a forma de interpretar a lei mudou para que o segmento pudesse se adaptar aos novos costumes da sociedade. Neste sentido, as águas minerais são hoje geridas pela finalidade (engarrafamento ou uso em balneários) independente de possuírem características químicas e físico-químicas peculiares ou de serem supostamente terapêuticas. A gestão das águas minerais fundamentada na finalidade foi necessária para compatibilizar a competência do DNPM aos novos princípios e diretrizes legais introduzidas pela Constituição e pela PNRH à gestão dos recursos hídricos subterrâneos.

$\mathrm{O}$ uso medicamentoso das águas minerais está hoje obsoleto, pois os médicos brasileiros deixaram de se especializar em Crenologia. No entanto, continuam válidos os preceitos contidos no CAM de que as águas minerais devem ser diferenciadas das águas comuns e devem ser protegidas da poluição superficial. Águas subterrâneas comuns podem apresentar flutuações composicionais, as minerais não. As águas minerais devem ser reconhecidas não somente pelo seu conteúdo (mineralização), mas principalmente por aquilo que não contém (poluentes). Mais ainda: as águas minerais devem ser de fato diferenciadas, não só quanto às características intrínsecas da água, mas também quanto aos aspectos hidrogeológicos do aquífero, principalmente no que se refere à sua vulnerabilidade natural e proteção inequívoca das fontes à influência antrópica. A gestão das águas minerais pelo DNPM poderia ser mais focada nas fontes e aquíferos, ou seja, no recurso propriamente dito e na regulamentação adequada do conceito de pureza original da água mineral, e menos no processo industrial e de produção de bens de consumo.

O outro passo necessário é retomar a discussão no âmbito governamental pela atualização do CAM, que conte com ampla participação da sociedade e dos diversos setores econômicos com interesses conflitantes no uso da água subterrânea mineralizada. A discussão deve abordar questões polêmicas, como por exemplo, a incompatibilidade do regime minerário com o princípio de inalienabilidade das águas subterrâneas como bens públicos de uso comum do povo.

Se a forma de interpretar o CAM mudou, principalmente quanto aos procedimentos de clas- sificação de uma água mineral, a gestão das águas minerais deveria também evoluir. É preciso acabar com o discurso falacioso que nega às águas minerais o status de recurso hídrico subterrâneo. A gestão isolada das águas minerais, no âmbito do CAM e fora da PNRH, ainda instiga conflitos e enterra soluções de consenso, assim como dificulta a colaboração de instituições públicas federais e estaduais e a interlocução com os setores com interesses conflitantes no uso de recursos hídricos subterrâneos.

Como estratégia institucional, o DNPM poderia exercer a gestão das águas minerais de forma colaborativa e compartilhada aos órgãos estaduais de recursos hídricos, reconhecendo a dimensão ambiental da água subterrânea introduzida pela Constituição, assim como os princípios do desenvolvimento sustentável difundidos pela legislação ambiental e de recursos hídricos vigentes no país. Para isso, o DNPM precisaria reformar seu posicionamento na CTAS/CNRH, de 2005, e efetivamente promover a integração da gestão das águas minerais às legislações estaduais que tratam da outorga de uso de recursos hídricos, no âmbito da PNRH, tal como defendido por CAETANO (2005), REIS (2005), GUIMARÃES (2009), SERRA (2009) e FERREIRA JUNIOR (2011). A outorga de uso de recursos hídricos para empreendimentos de água mineral não deveria ser vista como "mais uma burocracia", mas sim como uma etapa necessária que permita o controle qualitativo e quantitativo do uso de um recurso hídrico subterrâneo em consonância com a capacidade do aquífero e com os seus outros usos legítimos.

Ao reconhecer a dimensão ambiental da água subterrânea introduzida pela Constituição e ao seguir os princípios do desenvolvimento sustentável difundidos pela legislação ambiental e de recursos hídricos, a gestão das águas minerais pelo DNPM estaria genuinamente perseguindo o interesse nacional preconizado no Art. 176 da Constituição Federal.

\section{AGRADECIMENTOS}

Este trabalho contou com o suporte do DNPM e do CNPq, através do Programa Ciência Sem Fronteiras, durante a execução de estágio de pós-doutoramento da primeira autora na área de Direito Ambiental, na Universidade de Strathclyde, no Reino Unido, no período de 2012/2013. 


\section{REFERÊNCIAS BIBLIOGRÁFICAS}

ABINAM - ASSOCIAÇÃO BRASILEIRA DA INDÚSTRIA DE ÁGUAS MINERAIS. 2012. Termalismo: Desuso e Sucateamento. Revista Água e Vida, 72: 10-14.

ABIR - ASSOCIAÇÃO BRASILEIRA DA INDÚSTRIA DE REFRIGERANTES E DE BEBIDAS NÃO ALCOÓLICAS. 2011. BNA Brasil Relatório 2011: Consumo de todas as bebidas comerciais 2005-2010. Disponível em http://abir.org.br/2011/10/24/dados-demercado-2011. Acessado em 5 mai.2013.

ANDRADE, A.M.A.; ALMEIDA, L. 2012. Comportamento do nível potenciométrico do Aquífero Termal de Caldas Novas - GO e medidas de restrição e controle aplicadas pelo Departamento Nacional de Produção Mineral (DNPM). Águas Subterrâneas, 26(1): 99-112.

BERTOLO, R.A. 2006. Reflexões sobre a classificação e as características químicas da água mineral envasada do Brasil. In: ABAS, CONGRESSO BRASILEIRO DE ÁGUAS SUBTERRÂNEAS, 14, Curitiba, 18 p. (Revista Águas Subterrâneas, Suplemento).

BERTOLO, R.; HIRATA, R.; FERNANDES, A. 2007. Hidrogeoquímica das águas minerais envasadas do Brasil. Revista Brasileira de Geociências, 37: 515-529.

BRANDÃO, I.M.G.; VALSECKI JUNIOR, A. 1998. Análise da concentração de flúor em águas minerais na região de Araraquara, Brasil. Revista Panamericana de Salud Publica, 4(4): 238-242.

CAETANO, L.C. 2005. A política da água mineral: Uma proposta de integração para o Estado do Rio de Janeiro. Universidade Estadual de Campinas, Campinas, Tese de Doutorado, $329 \mathrm{p}$.

CASSUTO, D.N.; SAMPAIO, R.S.R. 2011. Water law in the United States and Brazil - Climate change \& two approaches to emerging water poverty. William and Mary Environmental Law and Policy Review, 35: 371-413.

DI PIETRO, M.S.Z. 2010. Uso privativo de bem público por particular. São Paulo, Revista dos Tribunais, $2^{\mathrm{a}}$ edição, $310 \mathrm{p}$.
DNPM - DEPARTAMENTO NACIONAL DE PRODUÇÃO MINERAL. 2010. Anuário Mineral Brasileiro 2010. DNPM, Brasília, 804 p. (Volume 38).

DNPM - DEPARTAMENTO NACIONAL DE PRODUÇÃO MINERAL. 2012. Sumário Mineral 2012. DNPM, Brasília, 110 p. (Volume 32).

DNPM - DEPARTAMENTO NACIONAL DE PRODUÇÃO MINERAL. 2013. Sumário Mineral 2013. DNPM, Brasília, 110 p. (Volume 33).

FERREIRA JUNIOR, V.O.C. 2011. O regime jurídico das águas minerais e a sustentabilidade ambiental. Pontifícia Universidade Católica do Paraná, Curitiba, Dissertação de Mestrado, $160 \mathrm{p}$.

FIORAVANTI, A.; CANTARINI, L.; GUIDELLI, G.M.; GALEAZZI, M. 2011. Mechanisms of action of spa therapies in rheumatic diseases: What scientific evidence is there? Rheumatology International, 31: 1-8.

GUIMARÃES, B.C. 2009. Direitos coletivos ambientais e a exploração (in)sustentável das águas minerais. Editora Mandamentos, Belo Horizonte, $231 \mathrm{p}$.

HERRMANN, H. 2007. Legislação mineral, ambiental e tributária. In: E.E. Campos, E.B. Frazão, G.D. Calaes, H. Herrmann (ed.) Agregados para a construção civil no Brasil: Contribuições para formulação de Políticas Públicas. Belo Horizonte, CETEC/SGM, p. 75-121.

KLEIN, C.A.; HUANG, L.Y. 2008. Cultural norms as a source of law: The example of bottled water. Cardozo Law Review, 30(2): 507-542.

LEME MACHADO, P.A. 2002. Recursos hídricos - Direito brasileiro e internacional. São Paulo, Malheiros, $216 \mathrm{p}$.

MOURÃO, M.B. 1992. Medicina Hidrológica: Moderna terapêutica das águas minerais e estâncias de cura. Secretaria Municipal de Educação, Poços de Caldas, 732 p.

NASERMOADDELI, A.; KAGAMIMORI, S. 2005. Balneotherapy in Medicine: A Review. Environmental Health and Preventive Medicine, 10: 171-179. 
PLATIKANOV, S.; GARCIA, V.; FONSECA, I.; RULLÁN, E.; DEVESA, R.; TAULER, R. 2012. Influence of minerals on the taste of bottled and tap water: A chemometric approach. Water Research, 30: 1-12.

POMPEU, C.T. 2010. Direito de Águas no Brasil. Editora Revista dos Tribunais, São Paulo, $2^{\mathrm{a}}$ edição, 475 p.

QUEIROZ, E.T. 2004. Águas Minerais do Brasil: Distribuição, classificação e importância econômica. DNPM, Brasília, 135 p. (Programa Nacional de Distritos Mineiros).

QUINTELA, M.M. 2003. Banhos que curam: Práticas termais em Portugal e no Brasil. Etnográfica, 7(1): 171-185.

QUINTELA, M.M. 2004a. Cura termal: Entre as práticas "populares" e os saberes "científicos". In: UNIVERSIDADE DE COIMBRA, CONGRESSO LUSO-AFROBRASILEIRO DE CIÊNCIAS SOCIAIS, 8, Coimbra, Portugal, Anais, 22 p.

QUINTELA, M.M. 2004b. Saberes e práticas termais: uma perspectiva comparada em Portugal (Termas de São Pedro do Sul) e no Brasil (Caldas da Imperatriz). História, Ciências, Saúde, 11(suplemento 1): 239-260.

REALE, M. 2000. Filosofia do Direito. Saraiva, São Paulo, $19^{\mathrm{a}}$ edição, 750 p.

REALE, M. 2001. Lições preliminares de Direito. Saraiva, São Paulo, 25 edição, 357 p.

REBOUÇAS, A.C. 2006. Águas subterrâneas. In: A.C. Rebouças, B. Braga, J.G Tundisi (org.) Águas Doces no Brasil. São Paulo, Editora Escrituras, $3^{\text {a }}$ edição, p. 111-144.

REIS, A.M. 2005. Desatando nós e tecendo novas linhas: Em busca de uma gestão integrada das águas minerais na legislação brasileira. In: W.P. Freitas (coord.), Direito Ambiental em Evolução, Curitiba, Editora Juruá, vol. 4, p. $15-40$.

SCALON, M.G.B. 2011. Águas minerais e recursos hídricos: uma perspectiva de gestão integrada. Revista de Direito, Estado e Recursos Naturais, 1(1): 131-160.

SERRA, S.H. 2000. A formação, os condicionamentos e a extinção dos direitos minerários. Universidade Estadual de Campinas, Campinas, Dissertação de Mestrado, 159 p.

SERRA, S.H. 2009. Águas Minerais do Brasil. Millennium Editora, Campinas, 291 p.

TRINDADE, A.D.C. 2009. Princípios do Direito Minerário. In: M.M.G. Souza (coord.) Direito Minerário em Evolução. Belo Horizonte, Editora Mandamentos, p. 47-76.

TRINDADE, A.D.C. 2011. Perspectivas para uma reforma da Legislação Mineral. In: J. Martins, P.C.R. Lima, A.P. Queiroz Filho, L.C. Schüller, R.C.M. Pontes (coord.) Setor Mineral: rumo ao novo marco legal. Brasília, Câmara dos Deputados, p. 205-220. (Série Cadernos de Altos Estudos, 8).

VACCAREZZA, M.; VITALE, M. 2010. Crenotherapy: A neglected resource for human health now re-emerging on sound scientific concepts. International Journal of Biometeorology, 54: 491-493.

VILLENA, R.S.; BORGES, D.G.; CURY, J.A. 1996. Avaliação da concentração de flúor em águas minerais comercializadas no Brasil. Revista de Saúde Pública, 30(6): 512-518.

WILK, R. 2006. Bottled water: The pure commodity in the age of branding. Journal of Consumer Culture, 6(3): 303-325.

WILTON, M. 2011. Global market trends and industry outlook. ABINAM, GLOBAL BOTTLED WATER CONGRESS, 8, Rio de Janeiro (palestra).

WHO - WORLD HEALTH ORGANIZATION. 2011. Guidelines for Drinking-Water Quality. WHO, Geneva, 4a edição, 541 p. Disponível em http://whqlibdoc.who.int/ publications/2011/9789241548151_eng.pdf. Acessado em 5 ago.2013. 
Endereço dos autores:

Ana Lúcia Desenzi Gesicki - Departamento Nacional de Produção Mineral, Superintendência de São Paulo (DNPM/SP), Rua Loefgreen, 2225, CEP: 04040-033, São Paulo, SP, Brasil. E-mail: ana.gesicki@, dpm.gov.br

Francesco Sindico - Strathclyde Centre for Environmental Law and Governance (SCELG), University of Strathclyde, 50 George Street, Graham Hills Building, Glasgow, UK, G1 1QE. E-mail: francesco. sindico@strath.ac.uk

Artigo submetido em 6 de maio de 2014, aceito em 16 de julho de 2014. 